\title{
Keterkaitan Arah Kebijakan Lingkungan Pasca Undang-Undang Tentang Cipta Kerja dengan Manajemen dan Kebijakan Lingkungan Sektor Militer
}

\author{
Eko Susdarwanto*, Endro Tri Susdarwono*** \\ Pemerintah Daerah, Kabupaten Tegal* \\ FISIP, Universitas Peradaban**`
}

dikirim: 7 September $2021 \quad$ direvisi:29 Desember 2021 diterima: 30 Desember 2021

\begin{abstract}
Abstrak:
Praktik Undang-Undang Cipta Kerja terkait lingkungan berpengaruh terhadap manajemen lingkungan militer berupa penyiapan dan penataan wilayah negara sebagai medan pertahanan dan penyiapan logistik wilayah. Penelitian ini bertujuan meneliti mengenai keterkaitan arah pembangunan pasca Undang-Undang Cipta Kerja dengan manajemen dan kebijakan lingkungan sektor lingkungan. Dalam penelitian ini pendekatan yang digunakan adalah kombinasi antara kualitatif dan kuantitatif. Metode pendekatan kualitatif yang digunakan adalah yuridis normatif analitis substansi hukum sedangkan pendekatan kuantitatif menggunakan pengujian hipotesis atas tanda guna menganalisis dampak yang timbul karena terjadinya suatu hal. Kesimpulan dari penelitian ini adalah Undang-Undang Cipta Kerja dalam implementasinya berpotensi melemahkan instrumen yang terkait manajemen dan kebijakan lingkungan sektor militer yaitu perlindungan lingkungan hidup, hak-hak masyarakat dan juga berpotensi memberikan dampak negatif terhadap kualitas lingkungan hidup. Hal ini juga diperkuat dengan hasil pengujian hipotesis atas tanda bahwa terjadi perubahan dalam membangun respons manajemen lingkungan standar yang harus digunakan untuk semua komponen, sipil atau militer.
\end{abstract}

Kata Kunci : Lingkungan, Manajemen Lingkungan Militer, Undang-Undang Cipta Kerja.

\section{Abstract:}

The practice of the Job Creation Law related to the environment affects the management of the military environment in the form of preparing and structuring the country's territory as a defense field and preparing regional logistics. This study aims to examine the relationship between the direction of development after the Cipta Kerja Law with environmental management and policies in the environmental sector. In this research, the approach used is a combination of qualitative and quantitative. The qualitative approach method used is juridical normative analytical legal substance, while the quantitative approach uses hypothesis testing on signs in order to analyze the impact arising from the occurrence of a thing. The conclusion from this research is that the Job Creation Law in its implementation has the potential to weaken instruments related to environmental management and policy in the military sector, namely environmental protection, community rights and also has the potential to have a negative impact on environmental quality. This is also reinforced by the results of hypothesis testing on signs that there is a change in building a standard environmental management response that must be used for all components, civil or military.

Keywords : Environment, Military Environmental Management, Job Creation Law. 
Morality: Jurnal Ilmu Hulkum

\section{PENDAHULUAN}

Penyiapan potensi pertahanan yaitu potensi sumber daya nasional menjadi kekuatan pertahanan negara, baik itu menyiapkan pembentukan kekuatan komponen cadangan, maupun penataan dan penyiapan komponen pendukung, yaitu penyiapan dan penataan wilayah negara sebagai medan pertahanan dan penyiapan logistic wilayah, sangatlah rumit karena bersentuhan langsung dengan rakyat atau warga negara. Penataan dan penyiapan wilayah pertahanan akan bertabrakan dengan kepentingan pembangunan atau kesejahteraan rakyat disebabkan permukaan tanah untuk beperang adalah hanya satu yaitu tanah yang digunakan untuk kepentingan pembangunan (Sebastian, 2017).

Sumber daya wilayah pertahanan selain apa yang telah disebutkan di atas, yaitu pada potensi pertahanan terutama yang menyangkut penggunaan tanah, bila sumber daya wilayah - apabila dianalogikan dengan pembinaan territorial - yaitu pembinaan geografi, demografi, dan kondisi social guna membangun ruang, alat dan kondisi juang (RAK Juang) dalam rangka mewujudkan sistem pertahanan keamanan rakyat semesta (Sishanmkamrata). Geografi adalah ruang, yang pada ruang tersebut disusun wilayah pertahanan, mulai daerah depan tempur
Desember 2021, Volume 7 Nomor 2

(daerah pertempuran), daerah komunikasi, killing ground, daerah logistic wilayah, dan sebagainya. Demikian pula unsur demografi, yang segera harus diatur dan ditata pada masa damai, siapa melakukan apa, dengan cara mengaktifkan regulasirgulasi untuk memenuhi komponen cadangan dan komponen pendukung. Kondisi social setali tiga uang. Penyususnan ketiga hal tersebut relative sulit dan tidak efektif apabila disusun pada saat perang berlangsung, oleh karena itu penyususnan daerah tersebut diatur pada masa damai. Namun di sisi lain, terutama dalam alam demokrasi seperti saat ini akan sangat sulit penyusunan daerah atau wilayah untuk kepentingan terselenggaranya

Sishamkamrata (Supriyatno, 2014).

Undang-Undang Cipta Kerja yang sudah disahkan sangat rentan bersinggungan dengan penyiapan potensi pertahanan di wilayah Indonesia disebabkan sistem pertahanan yang dianut Indonesia adalah sistem pertahanan rakyat semesta (sishanta). Dalam sisem pertahanan ini sangat menggantungkan terhadap pertahanan wilayah berupa lingkungan yang ada. Praktik Omnibus Law Cipta Kerja ini sangat memberikan potensi yang besar terhadap kerusakan lingkungan disebabkan investasi masih 
Morality: Jurnal Ilmu Hukum

yang tidak terlalu memperhatikan lingkungan hidup.

Secara terminologi Omnibus berasal dari bahasa Latin yang berarti untuk semuanya (Satria, 2020). Metode omnibus merupakan metode pembentukan peraturan perundang-undangan yang lazim diterapkan di berbagai negara untuk mempercepat proses legislasi, memudahkan harmonisasi peraturan, dan menghemat biaya penyusunan dan pembahasan (IOJI, 2020). Bryan A. Garner dalam Black Law Dictionary Ninth Edition menyebutkan bahwa omnibus merupakan "relating to or dealing with numerous object or item at once; including many thing or having various purposes" (Aulianisa, 2019). Fachri Bachmid menyatakan bahwa omnibus law merupakan suatu konsep produk hukum yang berfungsi untuk mengkonsolidir berbagai tema, materi, subjek, dan peraturan perundang-undangan pada setiap sektor yang berbeda untuk menjadi satu produk hukum besar dan holistic (Fitryantica, 2019). Dari segi hukum, kata Omnibus disandingkan dengan kata law yang berarti suatu peraturan yang dibuat berdasarkan hasil kompilasi beberapa aturan dengan substansi dan tingkatannya berbeda (Safitri, 2020).

Didalam proses perancangan RUU ini banyak sekali opini-opini masyarakat
Desember 2021, Volume 7 Nomor 2

yang tidak setuju dengan adanya RUU ini. Adanya opini-opini publik ini tidak lain disebabkan karena pengerjaannya yang di deadline hanya selama 100 hari oleh Presiden Jokowidan juga tidak melibatkan banyak pihak dalam pembuatannya (Kurniawan, 2020). Satu hal penting yang perlu digaris bawahi adalah UndangUndang Cipta Kerja tidak menjawab permasalahan pembangunan berkelanjutan yang secara faktual terjadi (ICEL, 2020). Undang-Undang Cipta Kerja juga mengabaikan prinsip perlindungan lingkungan hidup. Undang-Undang Cipta Kerja tidak mengadopsi prinsip atau asas pembangunan berkelanjutan atau yang terkait dengan pembangunan berkelanjutan sebagaimana tercantum dalam undangundang sektoral terkait pengelolaan sumber daya alam yang ada sekarang (ICEL, 2020).

Upaya maksimalisasi pemanfaatan sumber daya alam yang dimiliki sangat terlihat dalam Undang-Undang Cipta Kerja (IGJ, 2020). Investasi asing yang masuk ke Indonesia akan dibarengi masuknya teknologi dan pengetahuan yang nantinya dapat ditiru serta dikembangkan oleh masyarakat (Prabowo et al., 2020). Namun investasi yang tidak selektif dapat menimbulkan potensi yang besar terhadap kerusakan lingkungan di Indonesia. Dalam Undang-Undang Cipta Kerja terdapat 
Morality: Jurnal Ilmu Hukum

penafian terhadap partisipasi masyarakat dalam proses penyusunan kebijakan dan dokumen lingkungan hidup, padahal dengan adanya partisipasi ini sangat diharapkan pelaku usaha atau masyarakat mampu meminimalisis terjadinya pencemaran dan atau kerusakan lingkungan hidup dalam artian adanya ketaatan terhadap instrument perizinan lingkungan hidup (Nugroho, 2017).

Penelitian ini bermaksud memberikan deskripsi mengenai keterkaitan arah kebijakan lingkungan pasca praktik Omnibus Law UndangUndang tentang Cipta Kerja dengan manajemen dan kebijakan lingkungan sektor militer. Penelitian ini bertujuan meneliti mengenai keterkaitan arah pembangunan pasca Undang-Undang Cipta Kerja dengan manajemen dan kebijakan lingkungan sektor lingkungan. Dalam penelitian ini pendekatan yang digunakan adalah kombinasi antara kualitatif dan kuantitatif. Metode pendekatan kualitatif yang digunakan adalah yuridis normatif analitis substansi hukum (Muhammad, 2004) sedangkan pendekatan kuantitatif menggunakan pengujian hipotesis atas tanda guna menganalisis dampak yang timbul karena terjadinya suatu hal (Lestari \& Yudhanegara, 2017).
Desember 2021, Volume 7 Nomor 2

\section{PEMBAHASAN}

Isu lingkungan telah bergulir menjadi isu dan kepentingan setiap negara di dunia. Dalam dunia yang menghadapi ancaman perubahan iklim yang sangat ekstrim, menjaga keberlanjutan lingkungan (the sustainability of environment) merupakan satu pilihan opsi untuk mencegah efek negatif. Manusia mempunyai tanggung jawab untuk menjaga kondisi lingkungan yang ada dengan baik, maka ruang hidup (the living space) tetap eksis atau terjaga, dan tetap mendukung kesehatan dan membawa berbagai keuntungan bagi kehidupan makhluk hidup.

Pada saat ini, seluruh masyarakat dunia dan seluruh pemerintahan memiliki tanggung jawab yang sama untuk menjaga lingkungan dalam rangka menghindari ancaman bagi lingkungan hidup. Melalui penerapan norma-norma lingkungan hidup, dunia memiliki kesempatan yang besar untuk menghindari dari kehancuran. Militer salah satu actor yang memiliki tanggung jawab terhadap tetap terjaganya lingkungan hidup dari penurunan kualitas lingkungan hidup. Militer juga memiliki harapan untuk mengimplementasikan apa yang disebut denan suatu konsep lingkungan yang bersahabat atau "an environtmental friendly concept" dalam setiap aktivitasnya, memainkanperan aktif dalam menjaga degradasi lingkungan dan 
Morality: Jurnal Ilmu Hukum

pemangunan berkelanjutan dalam sebuah negara. Dari alasan itu, penerapan normanorma lingkungan di dan oleh organisasi militer merupakan bagian dari solusi untuk menjaga kerusakan lingkungan. Untuk itu manajemen lingkungan pertahanan harus segera dipikirkan, karena akan membahayakan kehidupan umat manusia di masa mendatang, dan militer atau bidang pertahanan harus memberi kontribusi positif terhadap lingkungan yang bersih dan hijau.

Kebijakan nasional lingkungan hidup untuk pengembangan dan secara khususnya kebijakan manajemen lingkungan hidup untuk menjamin keberlanjutan konservasi dan kemampuan lingkungan. Kasus di Indonesia, manajemen lingkungan hidup merupakan
Desember 2021, Volume 7 Nomor 2

bagian dari program nasional pengembangan seperti tercantum dalam Pasal 28 (1) dan 33 dari UUD 1945. Sejalan dengan itu, Pasal 3 UU No. 23/1997 tentang Pengelolaan Lingkungan Hidup menjelaskan bahwa pengelolaan lingkungan hidup diselenggarakan dengan ass tanggung jawab negara, asas berkelanjutan, dan asas manfaat bertujuan untuk pembangunan manusia Indonesia.

Lebih dari itu, Peraturan Pemerintah No. 27/1999 mengenai Analisis Dampak Lingkungan dan Keputusan Menteri Lingkungan Hidup No. 17/2001 tentang Rencana Kegiatan dan atau Kegiatan yang perlu di AMDAL termasuk di dalamnya kegiatan-kegiatan militer, seperti berikut ini:

Tabel 1.

Rencana Kegiatan dan atau Kegiatan Militer yang perlu di AMDAL

\begin{tabular}{|c|c|c|c|}
\hline No & Bentuk Kegiatan & Skala & Scientific Reasons \\
\hline 1 & Gudang amunisi & Berbagai ukuran & $\begin{array}{l}\text { Risiko meledak dalam perjalanan dan proses } \\
\text { penggudangan, walaupun sudah ada Standard } \\
\text { Operation Procedure (SOP) penanganan material } \\
\text { eksplosif }\end{array}$ \\
\hline 2 & $\begin{array}{l}\text { Gedung } \quad \text { Markas } \\
\text { Angkatan Laut (building } \\
\text { navy base) }\end{array}$ & Tipe A \& B & $\begin{array}{l}\text { - Kegiatan reklamasi dalam kegiatan yang } \\
\text { berpotensi akan merubah ekosistem. } \\
\text { - Kegiatan di markas yang berpotensi pembuangan } \\
\text { limbah cair dan padat (liquid and silid wastes) }\end{array}$ \\
\hline 3 & $\begin{array}{lr}\text { Gedung } & \text { Markas } \\
\text { Angkatan } & \text { Udara } \\
\text { (building air force base) }\end{array}$ & Tipe A \& B & $\begin{array}{l}\text { Kegiatan di markas yang berpotensi pembuangan } \\
\text { limbah cair dan padat dan bising }\end{array}$ \\
\hline 4 & $\begin{array}{l}\text { Gedung tempat latihan } \\
\text { perang (building combat } \\
\text { training area) }\end{array}$ & Di atas 10.000 are & $\begin{array}{l}\text { - Markas dan fasilitas pendukung termasuk buffer } \\
\text { zone, area terlarang untuk masyarakt. } \\
\text { - Kegiatan di markas yang berpotensi pembuangan } \\
\text { limbah cair dan padat dan bising karena ledakan }\end{array}$ \\
\hline 5 & Tempat/lapangan tembak & Di atas 10.000 are & $\begin{array}{l}\text { - Markas dan fasilitas pendukung termasuk buffer } \\
\text { zone, area terlarang untuk masyarakat. } \\
\text { - Kegiatan di markas yang berpotensi pembuangan } \\
\text { limbah cair dan padat dan bising karena ledakan. }\end{array}$ \\
\hline
\end{tabular}


Untuk memastikan pengolahan dan pembuangan limbah berbahaya yang dilakukan menurut norma-norma lingkungan nasional, pemerintah mengambil beberapa langkah: kampanye pengurangan limbah nasional, mereapkan pendekatan sistem manajemen lingkungan, eco-labeling, dan $4 \mathrm{R}$ (research/penelitian, reasons/alasan, relation/berhubungan, dan record/catatan) prinsip. Upaya pemerintah juga mencakup pengenalan teknologi baru dan fasilitas pengolahan bahan untuk limbah berbahaya.

Manajemen lingkungan merupakan salah satu dari beberapa prinsip dasar pertahanan negara, sebagaimana tercantum dalam pasal 3 Undang-Undang Nomor 3/2002 tentang Pertahanan Negara. Pasal 3 menyatakan Pertahanan negara disusun berdasarkan prinsip demokrasi, hak asasi manusia, kesejahteraan umum, lingkungan hidup, ketentuan hukum nasional, hukum internasional dan kebiasaan internasional, serta prinsip hidup berdampingan secara damai. Perlindungan lingkungan berfungsi sebagai pedoman penting dan pertimbangan utama dalam pertahanan negara. Terlebih lagi, doktrin pertahanan negara dan strategi menekankanperhatian khusus bagi TNI untuk melakukan fungsi rehabilitasi, terutama pada dampak yang disebabkan oleh latihan militer atau kegiatan lainnya. Pertahanan Indonesia juga selaras dengan konvensi internasional, terutama global dan perjanjian lingkungan regional. Militer perlu menyadari bahwa mereka memiliki kewajiban dalam menangani masalah keamanan lingkungan. Militer juga harus siap untuk mengatasi bencana alam, bencana teknologi, kerja dengan nuklir, senjata biologi atau kimia atau distribusi bahan radioaktif, masalah polusi, dan kesehatan masyarakat, dan lain-lain, karena ini adalah masalah sulit tetapi menantang militer danharus dilakuan pada saat ini juga, apabila tidak, akan berbahaya di kemudian hari.

Memang benar bahwa beberapa kegiatan militer, dalam masa damai memiliki beberapa bentuk yang berdampak pada lingkungan. Hal ini karena Angkatan bersenjata berusaha untuk mempersiapkan masa damai untuk operasi perang dalam kondisi serealitstis munkin. Militer melakukan banyak hal, di dalam atau di luar pangkalan mereka, yang mungkin menghasilkan bahan kimia yang tidak aman bagi lingkungan. Tapi, TNI memiliki manajemen standar yang selalu dipatuhinya aturan dan peraturan untuk perlindungan lingkungan, mengikuti standar yang diperlukan, dan desain rencana yang tepat dalam mendukung 
Morality: Jurnal Ilmu Hukum

pencapaian pembangunan berkelanjutan. Peraturan tersebut tertera dalam Pasal 28 (1) dan 33 UUD 1945, Pasal 3 UU No. 23/1997, Peraturan Pemerintah No. 27/1999, dan Keputusan Menteri Lingkungan Hidup No. 17/2001 tentang Rencana Kegiatan dan atau Kegiatan yang perlu di AMDAL termasuk di dalamnya kegiatan-kegiatan militer. Dengan demikian, TNI sering bekerja sama dengan otoritas sipil, khususnya mereka yang peduli dengan perlindungan lingkungan. Saluran komunikasi antara TNI dan otoritas sipil juga dibentuk untuk meningkatkan koordinasi. Koordinasi antara Nubika (satuan nuklir, biologi, dan kimia) dengan pemerintah daerah. Badan Pengawas Tenaga Nuklir (Bapeten), Badan Tenaga Nuklri Nasional (BATAN), dan Kementerian Kesehatan.

Secara internal, TNI telah meletakkan tujan dan proposan untuk aksi lingkungan untuk membantu mengurangi dampak lingkungan dan menyampaikan laporan mengidentifikasi implikasi lingkungan yang disebabkan oleh kegiatan-kegiatan militer, dan terusmenerus membuat analisa dampak lingkungan sebelum proyek baru dimulai. Hingga saat ini, dampak lingkunga yang langka. Namun TNI terus melakukan kerusakan penilaian lingkungan. Penerapan norma-norma lingkungan TNI
Desember 2021, Volume 7 Nomor 2

tidak hanya dapat dilihat dalam praktik shari-hari dan operasi. TNI juga terlibat dalam melindungi lingkungan danpenanggulangan bencana dalam konteks operasi militer selain perang. Contoh kontribusi TNI adalah pelaksanaan TNI Manunggal Masuk Desa (TMMD). Dalam program ini TNI membantu masyarakat dan melindungi lingkungan mereka. Melalaui program ini, beberapa pengetahuan tentang isu-isu lingkungan hidup juga diberikan kepada orang-orang.

Ancaman dari merendahkan lingkungan tidak berhenti di perbatasan suatu negara tetapi mungkin menyeberang perbatasan tanpa Batasan. TNI telah dikeluarkan upaya yang luar biasa dan sumber daya untuk menghadap bahaya ini dengan mengadopsi strategi lingkungan militer yang sesuai dengan tanggung jawab masing-masing. TNI juga melakukan penilaian dan pemantauan masalah lingkungan, mencari solusi yang cocok, dan memasok semua sumber daya keuangan dan manusia yang diperlukan. Dalam konteks manajemen bencana alam, TNI memiliki pesawat terbang, kapal, alat berat, keahlian, dan sumber daya manusia yang emmainkan peran penting dalam respon dan pencegahan bencana, termasuk informasi intelijen. Peran TNI dalam masa damai dalam melindungi lingkungan meningkat dengan baik dengan 
Morality: Jurnal Ilmu Hukum

meningkatkan tingkat pendidikan untuk pencegahan kerusakan atau kontaminasi untuk kedua personil militer dan sipil.

TNI selalu aktif berkontribusi dalam membersihkan ranjau darat, di darat, dan di laut dalam yurisdiksi nasional, yang bisa merugikan rakyat. Pelaksanaan perencanaan yang baik, prinsip seperti dalam kasus latihan militer di zona tertentu dan menghindari gangguan kepada masyarakat, mencegah polusi ata pencemaran bahan kimia, membersihkan area latihan, dan pembuangan amunisi di lokasi tertentu dilakukan secara sangat prosedur. Dalam hal ini, kontribusi TNI dalam melindungi lingkungan tidak dapat diabaikan.

Dalam penerapan norma-norma lingkungan dengan pembentukan militer, setiap pemerintah harus mengambil langkah-langkah:

a. Membangun respons manajemen lingkungan standar yang harus digunakan untuk semua komponen, sipil atau militer.

b. Bentuk saluran komunikasi langsung antara otoritas pertahanan dan lingkungan, dan menignkatkan koordinasi multilateral dan antar di tingkat nasional atau regional.

c. Terus melakukan upaya Confidence Building Measures antarnegara.

d. Bentuk kode etik dalam latihan militer bersama untuk mencegah pencemaran lingkungan atau kontaminasi.
Desember 2021, Volume 7 Nomor 2

Praktik UU Cipta Kerja terkait lingkungan berpengaruh terhadap manajemen lingkungan militer berupa penyiapan dan penataan wilayah negara sebagai medan pertahanan dan penyiapan logistik wilayah. Menganalisis definisi secara umum, Omnibus Law dapat dimaknai suatu perangkat Undang-Undang (UU) yang dalam proses pembuatan utamanya pembahasannya menyasar suatu isi besar. Isu ini sangat dimungkinkan akan mencabut dan mengubah adanya UndangUndang (UU) yang sudah eksis atau diterapkan secara sekaligus dengan tujuan menjadikannya lebih sederhana. Memang jika dimaknai dari sisi pemerintah, terdapat 3 (tiga) manfaat dari adanya penerapan Omnibus Law yang meliputi: praktik untuk menghindari adanya tumpang tindih peraturan perundangan, praktik dalam rangka efisiensi proses perubahan peraturan perundangan, dan praktik menghindari ego sectoral dalam berbagai peraturan perundangan.

Akan tetapi jika kita melihat dari sisi lain, adanya praktik penerapan Omnibus Law secara tidak hati hati ini akan membawa ancaman besar berupa terjadinya kerusakan lingkungan. Praktik ini akan memberikan legitimasi bagi masuknya investasi besar yang besar kemungkinan akan terkait dengan kerusakan lingkungan dan penurunan 
Morality: Jurnal Ilmu Hukum

terhadap kesejahteraan masyarakat. Kemungkinan besar ini akan terjadi dalam hal pemerintah tidak selektif dalam menentukan investasi yang masuk ke Indonesia. Potensi terjadinya perluasan eksploitasi sumber daya alam dan adanya kerusakan lingkungan hampir dapat dipastikan jikalau investor yang dimaksud masuk ke Indonesia. Jika dianalisis dan kemudian dideskripsikan lebih lanjut, praktik Omnibus Law ini berpotensi mendorong terjadinya percepatan terhadap krisis lingkungan hidup. Investasi massif yang masuk jelas meningkatkan bencana ekologis, terjadinya pencemaran dan degradasi lingkungan berupa adanya kerusakan. Bencana ekologis sudah dapat dilihat secara kasat mata berupa kebakaran hutan dan lahan dalam beberapa tahun ini, adanya kekeringan karena perubahan iklim, banjir, polusi udara yang sangat masif, dan lubang tambang menganga yang menyebabkan hilangnya nya puluhan anak.

Jikalau kita mengarahkan pandangan lain yang menegasikan tren investasi, terlihat jelas terjadinya pergeseran dalam postur ketenagakerjaan. Pergeseran sektor primer (perkebunan, pertanian, perikanan, pertambangan) ke sektor sekunder (industri) dan tersier (jasa, transportasi, perdagangan) terjadi dengan nyata. Adanya UU Cipta kerja menjanjikan
Desember 2021, Volume 7 Nomor 2

kemudahan dalam berusaha untuk kegiatan ekstraktif, meliputi kehutanan, perkebunan bahkan pertambangan. Pelonggaran bagi pelaku usaha dalam hal pertanggungjawaban terhadap lingkungan hidup diberikan secara definitif. Dan lebih khusus lagi adanya penyempitan bagi partisipasi public dalam hal penyusunan Amdal yang kemudian mengkhususkan pada masyarakat terdampak. (ICEL, 2020).

Berikut diberikan analisis untuk selanjutnya dilakukan pengujian hipotesis atas tanda Undang-Undang (UU) yang terdampak baik secara langsung maupun tidak langsung dengan adanya praktik UU Cipta Kerja terutama sekali terkait dengan lingkungan yang berpengaruh terhadap manajemen lingkungan militer berupa penyiapan dan penataan wilayah negara sebagai medan pertahanan dan penyiapan logistik wilayah.

1. UU No. 32 Tahun 2009 tentang Perlindungan dan Pengelolaan Lingkungan Hidup atau Persetujuan

\section{Lingkungan}

Pereduksian yang cukup signifikan terhadap masyarakat berupa hak akses informasi, partisipasi dan keadilan dan disertai dengan penghapusan hak akses tersebut. Sebagai contoh kesempatan berpartisipasi yang hilang dalam pengajuan keberatan dan penilaian 
terhadap AMDAL. Potensi hilangnya akses masyarakat dalam menggugat merupakan perwujudan dari dihapusnya izin lingkungan. Ketidakcermatan dalam penghapusan pasal dalam UU ini akan menjadi permasalahan tersendiri dikemudian hari meskipun juga tidak dinafikan bahwa banyak juga ketentuan yang baik dalam UU Cipta Kerja ini, akan tetapi jumlanya hanya minoritas jika dibandingkan masalah dan potensi masalah yang akan timbul.

\section{UU No. 41 Tahun 1999 tentang} Kehutanan sebagaimana diubah dengan UU No. 19 Tahun 2004

Dalam UU tentang Kehutanan terdapat perubahan yang cukup substansial. Perubahan ini mencakup ketentuan yang menghapus pasal tentang upaya mempertahankan minimal 30\% Kawasan hutan berdasarkan daerah aliran sungai (DAS) dan/atau pulau. Dalam rapat pembahasan terdapat penolakan fraksifraksi terhadap penghapusan pasal ini, namun penghapusan ini tetap diakomodir dalam UU Cipta Kerja. Perubahan kata “didasarkan" menjadi "mempertimbangkan" penelitian terpadu dalam peruntukan dan fungsi Kawasan hutan juga menjadi indikasi yang melemahkan UU No. 41 tahun 1999.

\section{UU No. 18 Tahun 2013 tentang Pencegahan dan Pemberantasan Perusakan Hutan}

Dua perubahan yang kiranya menjadi perhatian kita adalah kesatu ketentuan mengenai sanksi pidana penjara dan pidana denda, semula dalam draft Februari terjadi pengubahan menjadi “denda administratif” namun dikembalikan pada ketentuan menurut UU 18/2013. Memang pengaturan ini sesuai asas dan teori pemidaan, akan tetapi adanya penambahan satu ketentuan lagi yaitu jikalau korporasi tidak menjalankan pidana, maka pengurus dapat dikenakan pidana badan menjadikan hal ini berpotensi melanggar HAM. Kedua, adanya pemberian sanksi administratif (dan pengecualiannya) bagi masyarakat adat yang tinggal di kawasan hutan, yang berpotensi mengkriminalisasikan masyarakat adat apabila tidak dibarengi dengan pendataan dan pengakuan hak masyarakat adat beserta hutannya yang tepat sasaran.

4. UU No. 39 Tahun 2014 tentang

\section{Perkebunan}

Terkait UU tentang Perkebunan, catatan utama yang harus diberikan adalah pengaturan lebih lanjut kewajiban memiliki Amdal, analisis risiko, dan sarana prasarana penanggulangan karhutla dalam PP. Di satu sisi kekuatan PP tentu 
Morality: Jurnal Ilmu Hukum

lebih lemah dari UU karena tidak dapat memberikan sanksi pidana apabila kewajiban yang diatur tidak dipenuhi. Di sisi lain, penilaian atas perubahan tersebut juga tidak dapat dilakukan sekarang karena masih harus menunggu PP tersebut terbit. Catatan lainnya adalah mengenai pengembalian beberapa pasal yang dalam RUU CK Draft Februari dihapus, namun akhirnya dikembalikan lagi dalam UU Cipta Kerja, seperti larangan pemindahan hak atas tanah, kewajiban mengusahakan lahan dalam jangka waktu tertentu setelah mendapatkan izin, dan pengaturan mengenai fasilitasi kebun masyarakat(plasma) $20 \%$.

5. UU No. 26 Tahun 2007 tentang

\section{Penataan Ruang}

Terkait UU Penataan Ruang, secara garis besar ketentuan yang diubah lebih terkait dengan relaksasi dalam perihal prosedur penyelenggaraan penataan ruang. Sebenarnya relaksasi ini hal yang positif karena tujuan utamanya adalah pengakomodasian kebijakan nasional yang memiliki sifat strategis. Akan tetapi tidak adanya penjelasan tentang apa yang dimaksud apa dan bagaimana sebenarnya lingkup kebijakan nasional strategis yang dapat mempengaruhi penyelenggaraan penataan ruang tersebut. Hal ini dikhawatirkan akan mereduksi peran instrumen tata ruang sebagai instrumen
Desember 2021, Volume 7 Nomor 2

pencegahan pencemaran dan/atau kerusakan lingkungan hidup, serta instrumen untuk memastikan terselenggaranya pembangunan berkelanjutan.

Dari deskripsi analisis pendekatan kualitatif diatas untuk selanjutnya dilakukan pendekatan kuantitatif berupa pengujian hipotesis atas tanda terhadap UU diatas terkait dengan lingkungan yang berpengaruh terhadap manajemen lingkungan militer berupa penyiapan dan penataan wilayah negara sebagai medan pertahanan dan penyiapan logistik wilayah. Beberapa langkah pengujian hipotesis yang harus dilakukan di antaranya adalah:

Penelitian ini untuk teknik dalam penganalisisan data menerapkan pengujian hipotesis atas tanda guna menganalisis terhadap dampak yang terjadi disebabkan terjadinya suatu hal. Kelebihan dari pengujian hipotesis atas tanda dapat menganalisis dampat-dampak yang terjadi disebabkan adanya suatu perubahan terhadap peraturan tertentu. Merumuskan hipotesis nihil dan hipotesis alternative. Hipotesis nihil pada intinya menyatakan bahwa tidak terjadi perubahan materi yang mendukung manajemen dan kebijakan lingkungan sector militer terhadap UU Nomor 32 Tahun 2009, UU Nomor 41 Tahun 1999, UU Nomor 18 Tahun 2013, 
UU Nomor 39 Tahun 2014, dan UU Nomor 26 Tahun 2007. Sedangkan hipotesis alternative menyatakan bahwa terjadi perubahan materi yang mendukung manajemen dan kebijakan lingkungan sector militer terhadap UU Nomor 32 Tahun 2009, UU Nomor 41 Tahun 1999, UU Nomor 18 Tahun 2013, UU Nomor 39 Tahun 2014, dan UU Nomor 26 Tahun 2007.

Setelah kita melihat tampilan data dalam tabel, terlihat bahwa jumlah tanda negative lebih besar dibandingkan jumlah tanda positif. Dengan demikian, mengingat bahwa jumlah selisih negatif lebih besar, pengujian hipotesis yang diberlakukan adalah pengujian sisi kiri. Berkaitan dengan kasus ini, taraf signifikansi yang diberlakukan adalah 5\% atau 0,05. Dalam tabel khai-kuadrat, nilai khai-kuadrat untuk derajat kebebasan sebesar 1 dan taraf signifikansi 0,05 adalah 3,841 . Sedangkan untuk kriteria pengujian kasus ini, pengujian hipotesis yang diberlakukan adalah pengujian sisi kiri. Maka, kriteria pengujian yang diberlakukan dalam kasus ini adalah bahwa hipotesis nihil diterima apabila

$$
x^{2} \geq 3,841
$$

Sedangkan hipotesis nihil ditolak jika

$$
x^{2}<3,841
$$

Sehingga, berdasarkan rumus untuk menghitung nilai khai-kuadrat yang telah ditampilkan, nilai khai-kuadratnya adalah sebesar

$$
x^{2}=\frac{\left[\left(n_{1}-n_{2}\right)-1\right]^{2}}{n_{1}+n_{2}}
$$

Tabel 2.

Pengujian Hipotesis atas Tanda Undang-Undang Nomor 32 Tahun 2009

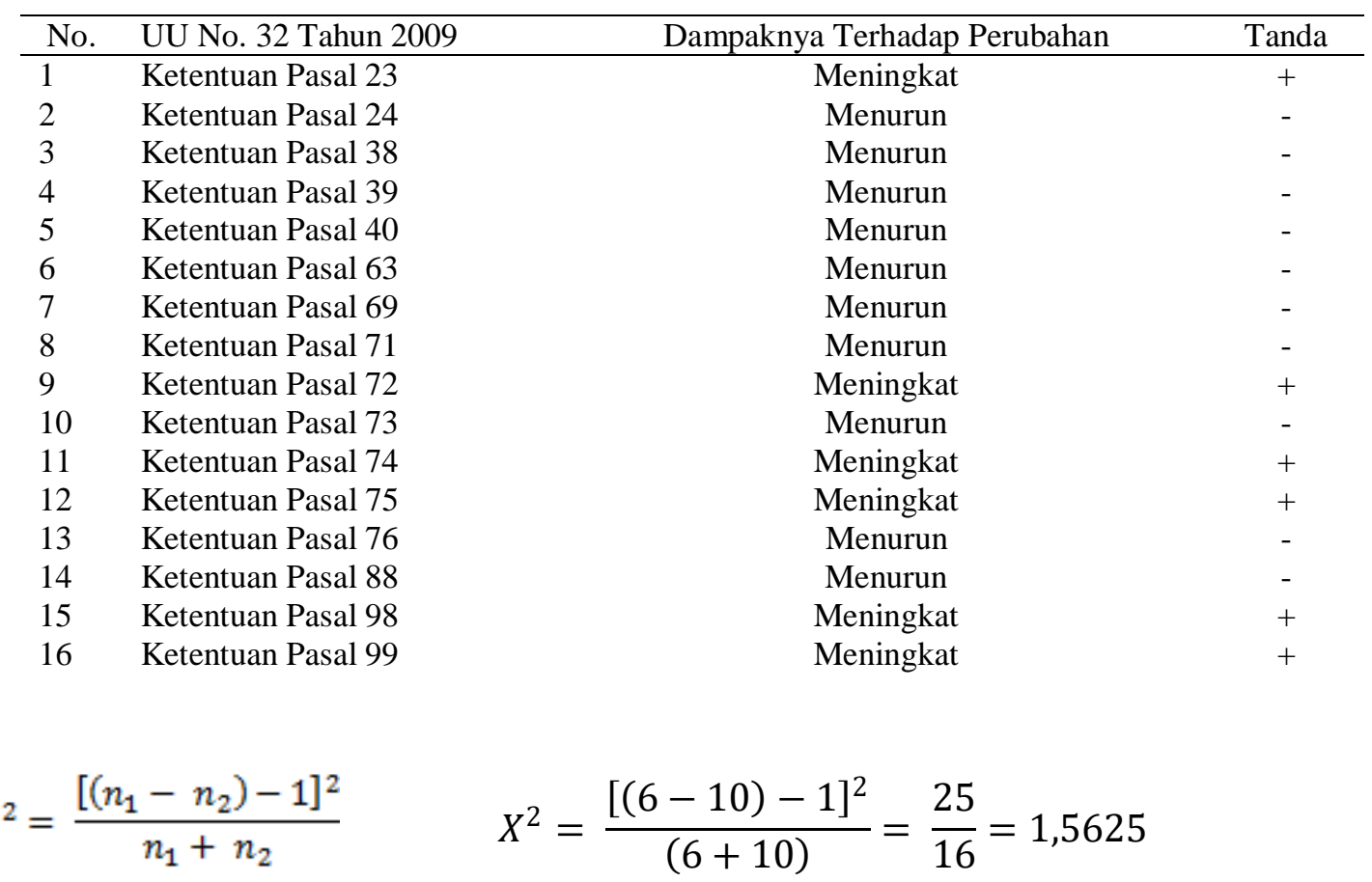


Berdasarkan atas hasil perhitungan di atas, nilai khai-kuadrat adalah 1,5625. Nilai khai-kuadrat itu lebih kecil daripada nilai khai-kuadrat dalam tabel sebesar 3,841. Dengan demikian, hipotesis nihil yang menyatakan bahwa tidak terjadi perubahan materi UU Nomor 32 Tahun 2009 yang mendukung manajemen dan kebijakan lingkungan sektor militer ditolak. Sebaliknya, hipotesis alternative yang menyatakan bahwa terjadi perubahan materi UU Nomor 32 Tahun 2009 yang mendukung manajemen dan kebijakan lingkungan sektor milite diterima.

Tabel 3.

Pengujian Hipotesis atas Tanda Undang-Undang Nomor 41 Tahun 1999

\begin{tabular}{llcc}
\hline No. & UU No. 41 Tahun 1999 & Dampaknya Terhadap Perubahan & Tanda \\
\hline 1 & Ketentuan Pasal 18 & Menurun & - \\
2 & Ketentuan Pasal 19 & Menurun & - \\
3 & Ketentuan Pasal 49 & Meningkat & + \\
4 & Ketentuan Pasal 50 & Meningkat & + \\
5 & Ketentuan Pasal 77 & Menurun & - \\
\hline
\end{tabular}

$$
x^{2}=\frac{\left[\left(n_{1}-n_{2}\right)-1\right]^{2}}{n_{1}+n_{2}} \quad X^{2}=\frac{[(2-3)-1]^{2}}{(2+3)}=\frac{4}{5}=0,8
$$

Berdasarkan atas hasil perhitungan di atas, nilai khai-kuadrat adalah 0,8 . Nilai khaikuadrat itu lebih kecil daripada nilai khaikuadrat dalam tabel sebesar 3,841. Dengan demikian, hipotesis nihil yang menyatakan bahwa tidak terjadi perubahan materi UU Nomor 41 Tahun 1999 yang mendukung manajemen dan kebijakan lingkungan sektor militer ditolak. Sebaliknya, hipotesis alternative yang menyatakan bahwa terjadi perubahan materi UU Nomor 41 Tahun 1999 yang mendukung manajemen dan kebijakan lingkungan sektor militer diterima.

Tabel 4.

Pengujian Hipotesis atas Tanda Undang-Undang Nomor 18 Tahun 2013

\begin{tabular}{llcc}
\hline No. & \multicolumn{1}{c}{ UU No. 18 Tahun 2013 } & Dampaknya Terhadap Perubahan & Tanda \\
\hline 1 & Ketentuan Pasal 18 & Meningkat & + \\
2 & Ketentuan Pasal 53 & Menurun & - \\
3 & Ketentuan Pasal 54 & Menurun & - \\
4 & Ketentuan Pasal 83 & Menurun & - \\
5 & Ketentuan Pasal 84 ayat (4) & Menurun & - \\
6 & Ketentuan Pasal 85 ayat (2) & Menurun & - \\
7 & Ketentuan Pasal 92 ayat (2) & Menurun & - \\
8 & Ketentuan Pasal 93 ayat (3) & Menurun & - \\
9 & Ketentuan Pasal 96 ayat (2) & Menurun & \\
\hline
\end{tabular}

$$
x^{2}=\frac{\left[\left(n_{1}-n_{2}\right)-1\right]^{2}}{n_{1}+n_{2}} \quad X^{2}=\frac{[(1-8)-1]^{2}}{(1+8)}=\frac{64}{9}=7,1111
$$


Berdasarkan atas hasil perhitungan di atas,

mendukung manajemen dan kebijakan nilai khai-kuadrat adalah 7,1111 . Nilai lingkungan sektor militer diterima. khai-kuadrat itu lebih besar daripada nilai khai-kuadrat dalam tabel sebesar 3,841. Dengan demikian, hipotesis nihil yang menyatakan bahwa tidak terjadi perubahan materi UU Nomor 18 Tahun 2013 yang Sebaliknya, hipotesis alternative yang menyatakan bahwa terjadi perubahan materi UU Nomor 18 Tahun 2013 yang mendukung manajemen dan kebijakan lingkungan sektor militer ditolak.

Tabel 5.

Pengujian Hipotesis atas Tanda Undang-Undang Nomor 39 Tahun 2014

\begin{tabular}{clcc}
\hline No. & \multicolumn{1}{c}{ UU No. 39 Tahun 2014 } & Dampaknya Terhadap Perubahan & Tanda \\
\hline 1 & Ketentuan Pasal 14 ayat (2) & Meningkat & + \\
2 & Ketentuan Pasal 15 & Menurun & - \\
3 & Ketentuan Pasal 16 ayat (1) & Meningkat & + \\
4 & Ketentuan Pasal 58 ayat (1) & Menurun & - \\
5 & Ketentuan Pasal 67 ayat (1) & Menurun & - \\
6 & Ketentuan Pasal 68 & Menurun & - \\
\hline
\end{tabular}

$$
x^{2}=\frac{\left[\left(n_{1}-n_{2}\right)-1\right]^{2}}{n_{1}+n_{2}} \quad X^{2}=\frac{[(2-4)-1]^{2}}{(2+4)}=\frac{9}{6}=1,5
$$

Berdasarkan atas hasil perhitungan di atas, manajemen dan kebijakan lingkungan nilai khai-kuadrat adalah 1,5. Nilai khai- sektor militer ditolak. Sebaliknya, kuadrat itu lebih kecil daripada nilai khaihipotesis alternative yang menyatakan kuadrat dalam tabel sebesar 3,841. Dengan bahwa terjadi perubahan materi UU demikian, hipotesis nihil yang menyatakan bahwa tidak terjadi perubahan materi UU Nomor 39 Tahun 2014 yang mendukung Nomor 39 Tahun 2014 yang mendukung manajemen dan kebijakan lingkungan sektor militer diterima.

Tabel 6.

Pengujian Hipotesis atas Tanda Undang-Undang Nomor 26 Tahun 2007

\begin{tabular}{llcc}
\hline No. & \multicolumn{1}{c}{ UU No. 26 Tahun 2007 } & Dampaknya Terhadap Perubahan & Tanda \\
\hline 1 & Ketentuan Pasal 6 ayat (5) & Menurun & - \\
2 & Ketentuan Pasal 10 ayat (1) & Menurun & - \\
3 & Ketentuan Pasal 11 & Menurun & - \\
4 & Ketentuan Pasal 17 ayat (1) & Menurun & - \\
5 & Ketentuan Pasal 20 ayat (5) & Meningkat & + \\
6 & Ketentuan Pasal 23 ayat (5) & Meningkat & + \\
7 & Ketentuan Pasal 26 ayat (6) & Meningkat & Menurun \\
8 & Ketentuan Pasal 60 & & - \\
& & & \\
$x^{2}=\frac{\left[\left(n_{1}-n_{2}\right)-1\right]^{2}}{n_{1}+n_{2}} \quad X^{2}=\frac{[(3-5)-1]^{2}}{(3+5)}=\frac{9}{8}=1,125$
\end{tabular}


Morality: Jurnal Ilmu Hukum

Berdasarkan atas hasil perhitungan di atas, nilai khai-kuadrat adalah 1,125. Nilai khaikuadrat itu lebih kecil daripada nilai khaikuadrat dalam tabel sebesar 3,841. Dengan demikian, hipotesis nihil yang menyatakan bahwa tidak terjadi perubahan materi UU Nomor 26 Tahun 2007 yang mendukung manajemen dan kebijakan lingkungan sektor militer ditolak. Sebaliknya, hipotesis alternative yang menyatakan bahwa terjadi perubahan materi UU Nomor 26 Tahun 2007 yang mendukung manajemen dan kebijakan lingkungan sektor militer diterima.

\section{KESIMPULAN}

Berdasarkan pengujian hipotesis atas tanda terhadap beberapa Undang-Undang terkait dengan lingkungan yang berpengaruh terhadap manajemen lingkungan militer berupa penyiapan dan penataan wilayah negara sebagai medan pertahanan dan penyiapan logistik wilayah pasca diterapkannya Omnibus Law dalam UU Cipta Kerja disimpulkan bahwa 1) terjadi perubahan materi yang mendukung manajemen dan kebijakan lingkungan sector militer terhadap UU Nomor 32 Tahun 2009, UU Nomor 41 Tahun 1999, UU Nomor 39 Tahun 2014, dan UU Nomor 26 Tahun 2007, 2) tidak terjadi perubahan materi yang mendukung manajemen dan kebijakan lingkungan
Desember 2021, Volume 7 Nomor 2

sector militer terhadap UU Nomor 18 Tahun 2013. UU Cipta Kerja dalam implementasinya berpotensi melemahkan instrumen yang terkait manajemen dan kebijakan lingkungan sector militer yaitu perlindungan lingkungan hidup, hak-hak masyarakat dan juga berpotensi memberikan dampak negatif terhadap kualitas lingkungan hidup. Hal ini juga diperkuat dengan hasil pengujian hipotesis atas tanda bahwa terjadi perubahan dalam membangun respons manajemen lingkungan standar yang harus digunakan untuk semua komponen, sipil atau militer.

\section{DAFTAR RUJUKAN}

Adhi Setyo Prabowo, Andhika Nugraha Triputra, Yoyok Junaidi, "Politik Hukum Omnibus Law di Indonesia,", Jurnal Pamator, Vol. 13, No. 1, April 2020.

Aulianisa, Sarah Safira. "Menakar Kompabilitas Transplantasi Omnibus Law dalam Konteks Peraturan Perundang-undangan dengan Sistem Hukum Indonesia. Paper dipresentasikan di Konferensi Ilmiah Hukum dan HAM 2019, Kementrian Hukum dan Hak Asasi Manusia.

Fitryantica, Agnes. "Harmonisasi Peraturan Perundang-Undangan Indonesia melalui Konsep Omnibus Law," Jurnal Gema Keadilan, Vol. 6, No.3, Oktober-November 2020.

https://jejakparlemen.id/rangkuman/BalegPanja-RUU-CiptaKerja-Lanjutan-CK, diakses 1 Desember 2020. 
Indonesia For Global Justice (IGJ), "RUU Omnibus Cipta Lapangan Kerja," Seri Framing Paper IGJ, April 2020.

Indonesia Ocean Justice Initiative, "Sistem dan Praktik Omnibus Law Diberbagai Negara dan Analisis RUU Cipta Kerja Dari Perspectif Good Legislation Making," Policy Brief 4, Agustus 2020.

Indonesian Center for Environmental Law, "Berbagai Problematika Dalam UU Cipta Kerja Sektor Lingkungan dan Sumber Daya Alam," Seri 3 Seri Analisis, 6 Oktober 2020.

Khaerudin \& Supandi. "Potensi Pertahanan di Indonesia sebagai Daya Dukung Pembangunan Nasional," Materi Kuliah Umum diProdi PPKn FKIP UNS, 8 September 2017

Kurniadi, A. (2014). Evaluasi Kebijakan Pelaksanaan Latihan Operasi Militer TNI AL Dalam Rangka Mempertahankan Stabilitas Ekosistem. Jurnal Green Growth Dan Manajemen Lingkungan, 3(1), 40 52.

Kurniawan, Fajar. "Problematika Pembentukan RUU Cipta Kerja dengan Konsep Omnibus Law Pada Klaster Ketenagakerjaan Pasal 89 Angka 45 Tentang Pemberian Pesangon Kepada Pekerja Yang Di PHK," Jurnal Panorama Hukum, Vol. 5, No. 1, Juni 2020.

Lestari, K.E., \& Yudhanegara, M.R. Penelitian Pendidikan Matematika. Bandung: Refika Aditama. 2017.

Muhammad, Abdulkadir. Hukum dan Penelitian Hukum. Bandung: Citra Aditya Bakti. 2004.
Nugroho, Wahyu. "Rekonstruksi Teori Hukum Pembangunan Kedalam Pembentukan Perundang-Undangan Lingkungan Hidup Dan Sumber Daya Alam Pasca Reformasi Dalam Bangunan Negara Hukum," Jurnal Legislasi Indonesia, Vol. 14, No. 4, Desember 2017.

Safitri, Dini. "Omnibus Law RUU Cipta Lapangan Kerja dalam Perspektif Komunikasi Pembangunan Partisipatif," Jurnal Dialog Kebijakan Publik, Juli 2020.

Satria, Adhi Putra. "Sibernetika Talcott Parsons: Suatu Analisis Terhadap Pelaksanaan Omnibus Law dalam Pembentukan Undang-Undang Cipta Lapangan Kerja di Indonesia," Indonesian State Law Review, Vol. 2, No. 2, April 2020.

Sebastian, Elly. "Peningkatan Peranan SDM Pertahanan Nasional Guna Menghadapi Perang Generasi Keempat," Jurnal Pertahanan, Vol 5, No. 1, April 2015, hlm. 110-128.

Supriyatno, Makmur. Tentang Ilmu Pertahanan. Jakarta: Yayasan Pustaka Obor Indonesia. 2014.

Warsono, Heribertus Yudho. "Kontribusi Operasi Tindakan Perlawanan Ranjau (TPR) Dalam Rangka Mendukung Pembangunan Maritim,", Cakrawala, Edisi 427 Tahun 2015, hlm. 36. 